Marquette University

e-Publications@Marquette

4-2006

\title{
Thermal Stability and Degradation Kinetics of Poly(methyl Methacrylate)/Layered Copper Hydroxy Methacrylate Composites
}

\author{
Everson Kandare \\ Marquette University \\ Hongmei Deng \\ Marquette University \\ Dongyan Wang \\ Cornell University \\ Jeanne Hossenlopp \\ Marquette University, jeanne.hossenlopp@marquette.edu
}

Follow this and additional works at: https://epublications.marquette.edu/chem_fac

Part of the Chemistry Commons

\section{Recommended Citation}

Kandare, Everson; Deng, Hongmei; Wang, Dongyan; and Hossenlopp, Jeanne, "Thermal Stability and Degradation Kinetics of Poly(methyl Methacrylate)/Layered Copper Hydroxy Methacrylate Composites" (2006). Chemistry Faculty Research and Publications. 5.

https://epublications.marquette.edu/chem_fac/5 


\title{
Thermal Stability and Degradation Kinetics of Poly(methyl Methacrylate)/Layered Copper Hydroxy Methacrylate Composites
}

\author{
Everson Kandare \\ Department of Chemistry, Marquette University \\ Milwaukee, WI \\ Hongmei Deng \\ Department of Chemistry, Marquette University \\ Milwaukee, WI \\ Dongyan Wang \\ Department of Materials Science and Engineering, Cornell \\ University \\ 416 Bard Hall, Ithaca, NY \\ Jeanne M. Hossenlopp \\ Department of Chemistry, Marquette University \\ Milwaukee, WI
}

\begin{abstract}
:
Poly(methyl methacrylate) (PMMA)/copper hydroxy methacrylate (CHM) composites were prepared via solution blending and bulk polymerization. Addition of $3 \%$ by weight of the $\mathrm{CHM}$ additive using solution blending resulted in a significant increment $\left(\sim 45^{\circ} \mathrm{C}\right)$ in thermogravimetric
\end{abstract}

Polymers for Advanced Technology, Vol. 17, No. 4 (April 2006): pg. 312-319. DOI. This article is (C Wiley and permission has been granted for this version to appear in e-Publications@Marquette. Wiley does not grant permission for this article to be further copied/distributed or hosted elsewhere without the express permission from Wiley. 
analysis (TGA) $T_{50}$, the temperature at which $50 \%$ of the original polymeric mass is lost. The value $T_{50}$ increased by $30^{\circ} \mathrm{C}$ for a PMMA composite with $4 \%$ $\mathrm{CHM}$, synthesized via bulk polymerization. Activation energies, $E_{\mathrm{a}}$, were calculated as a function of conversion fractions (TGA decomposition profile) for the polymeric materials. Analysis of multiple heating rate data using the Flynn-Wall-Ozawa method resulted in $E_{a}$ values that were $50 \mathrm{~kJ} \mathrm{~mol}^{-1}$ higher for conversions above 0.5 in the solution blended composite compared to a reference sample of pure PMMA recrystallized from the same solvent. Similar results were obtained for bulk polymerization process with differences in $E_{a}$ values $>30 \mathrm{~kJ} \mathrm{~mol}^{-1}$ relative to pure PMMA. However, in contrast to previous studies of bulk polymerized samples, the solution-blended composite exhibited no improvement in cone calorimetry determination of total heat release as compared with the reference PMMA sample

Keywords: poly(methyl methacrylate), layered hydroxy salt, degradation, thermogravimetric analysis (TGA), composites.

\section{Introduction}

Inorganic/organic hybrid layered materials with nanodimensional interlayer spacings can form nanocomposites with polymers either via intercalation or exfoliation. ${ }^{1-7}$ Marked improvements, relative to the pure polymer, have been reported in physical properties of these nanocomposites including the tensile strength, tensile modulus, flexural strength, thermal, and corrosion stability compared to virgin polymers. ${ }^{8-15}$ In addition to natural cationic clays, synthetic anion clays such as layered double hydroxides and hydroxy double salts (HDSs) have been utilized for this purpose. ${ }^{16}$ HDSs are formed from two divalent metals and have the general formula $\left.\left[\mathrm{M}_{1-\mathrm{x}}^{2+} \mathrm{M}_{1+\mathrm{x}}^{i 2+}\right)(\mathrm{OH})_{3(1-\mathrm{y}) / \mathrm{n}}\right]^{+} \mathrm{A}_{(1+3 \mathrm{y}) / \mathrm{n}}^{\mathrm{n}-} \cdot \mathrm{mH}_{2} \mathrm{O}$, where $\mathrm{M}^{2+}$ and $\mathrm{M}^{2+}$ represent the different divalent metals and $A^{n-}$-represents the interlayer anions. Similarly, layered hydroxy salts (LHSs), with a general formula, $\mathrm{M}_{2}(\mathrm{OH})_{3}(\mathrm{An}) \cdot \mathrm{zH}_{2} \mathrm{O}$, consist of positively charged metal hydroxide layers and exchangeable interlayer anions, . The advantage of synthetic "clays" is the possibility of varying the identity and composition of constituent metal elements hence providing additional design parameters to optimize additive effects on the properties of the virgin polymer.

Thermal degradation patterns of poly(methyl methacrylate) (PMMA) and PMMA-clay nanocomposites have been extensively

Polymers for Advanced Technology, Vol. 17, No. 4 (April 2006): pg. 312-319. DOI. This article is (C Wiley and permission has been granted for this version to appear in e-Publications@Marquette. Wiley does not grant permission for this article to be further copied/distributed or hosted elsewhere without the express permission from Wiley. 
studied. ${ }^{17-20}$ Addition of copper-containing layered hydroxides to PMMA through bulk polymerization has been shown in previous work to result in a dramatic improvement in the thermal stability of the resultant composites. ${ }^{21}$ In particular, a significant reduction in the total heat release (THR) ( $20-30 \%)$ from combustion of the composites was observed using cone calorimetry for these microcomposites. However, the need to improve the HDS or LHS additive dispersion was noted and further work was needed to investigate the details of how the additives serve to enhance PMMA thermal stability. ${ }^{21}$ Nanoscale dispersion of the additives in the polymer matrix results in a large interfacial area between the polymer chains and the additive leading to physical property enhancements observed for polymer nanocomposites. In clay nanocomposites, typically nanodispersion occurs via intercalation and exfoliation. However, nanocomposites may be more broadly defined, as the dispersion of nano-sized particles in the polymer matrix, thus leading to polymer/additive interaction at the nanoscale. For example polymer nanocomposites containing metal, silica or metal oxide nanoparticles have been shown to exhibit enhanced mechanical, magnetic, optical, or electrical properties. ${ }^{8,12,15,22-24}$

In the work reported here, a LHS additive, copper hydroxy methacrylate ( $\mathrm{CHM}$ ) is added to PMMA via solution blending and bulk polymerization. Composites are analyzed using $\mathrm{X}$-ray diffraction (XRD), transmission electron microscopy (TEM), and Fourier transform infrared (FT-IR) spectroscopy. The effects of sample preparation method on the composite thermal stability are determined via thermogravimetric analysis (TGA), differential thermal analysis (DTA), and cone calorimetry. XRD analysis is used to follow the evolution of the copper content of the additive during heating in order to explore the potential roles that the metal may play in thermal stabilization of PMMA.

Kinetics studies of the thermal degradation of PMMA and its composites have also been shown to be helpful for analyzing thermal stabilization effects. ${ }^{25-31}$ In the work reported here, activation energies are determined via an isoconversional method over the range of massloss conversions (a) in multiple-heating-rate TGA experiments.

Polymers for Advanced Technology, Vol. 17, No. 4 (April 2006): pg. 312-319. DOI. This article is @ Wiley and permission has been granted for this version to appear in e-Publications@Marquette. Wiley does not grant permission for this article to be further copied/distributed or hosted elsewhere without the express permission from Wiley. 
NOT THE PUBLISHED VERSION; this is the author's final, peer-reviewed manuscript. The published version may be accessed by following the link in the citation at the bottom of the page.

\section{Experimental}

Monomeric methyl methacrylate (MMA), benzoyl peroxide (BPO) initiator, reagent grade acetone, $\mathrm{NaOH}$, and commercial PMMA (molecular weight of 996,000 $\mathrm{g} \mathrm{mol}^{-1}$ ) were obtained from Aldrich Chemical Co. Copper(II) methacrylate hydrate (97\%) $\left[\left(\mathrm{H}_{2} \mathrm{C}=\mathrm{C}\left(\mathrm{CH}_{3}\right) \mathrm{CO}_{2}\right)_{2} \mathrm{Cu} \cdot x \mathrm{H}_{2} \mathrm{O}\right]$ and FT-IR-grade $\mathrm{KBr}$ were obtained from Alfar Aesar. All chemicals were used without further purification with the exception of the MMA solution where the hydroquinone mono methyl ether inhibitor was removed by passing through an inhibitor removal column (Aldrich).

The LHS additive, CHM, was prepared via a standard literature method used for the preparation of isomorphic LHSs like $\mathrm{Cu}_{2}(\mathrm{OH})_{3}\left(\mathrm{CH}_{3} \mathrm{CO}_{2}\right) \cdot x \mathrm{H}_{2} \mathrm{O} .{ }^{32} \mathrm{NaOH}(0.1 \mathrm{M} ; 500 \mathrm{ml})$ was added in a dropwise fashion to $500 \mathrm{ml}$ of $0.1 \mathrm{M}$ copper(II) methacrylate hydrate yielding a pH of $8.1 \pm 0.1$. The dispersion was filtered, washed, and dried at room temperature.

A 3\% loaded PMMA/layered CHM (PMMA/CHM-3) composite was made via solution blending by mixing $97 \mathrm{~g}$ of the commercial PMMA, dissolved in $800 \mathrm{ml}$ of acetone for $3 \mathrm{hr}$, with $3 \mathrm{~g}$ of CHM which had been dispersed in $200 \mathrm{ml}$ of acetone for $1 \mathrm{hr}$. The resultant mixture was mechanically stirred for $96 \mathrm{hr}$. The resulting viscous liquid was poured out onto an aluminum foil boat to maximize the evaporation of acetone. The composite was then oven dried at $100^{\circ} \mathrm{C}$ for $6 \mathrm{hr}$ after which it was crushed and dried again until a constant mass was achieved. A reference sample was made from dissolving $100 \mathrm{~g}$ of commercial PMMA in $1 \mathrm{I}$ of acetone then allowing the solvent to evaporate. This sample, (PMMA/ CHM-0) was cured in the same way as PMMA/CHM-3.

A 4\% CHM loaded PMMA composite (PMMA/CHM-4B) was synthesized via bulk polymerization as described previously. ${ }^{21} \mathrm{MMA}$ monomer was introduced into a $200 \mathrm{ml}$ beaker together with the initiator, BPO $(1 \%)$, and the CHM additive. The mixture was initially heated to $90^{\circ} \mathrm{C}$ with vigorous stirring until viscous after which the temperature was then lowered to $60^{\circ} \mathrm{C}$ and held constant for $24 \mathrm{hr}$. The temperature was then raised to $80^{\circ} \mathrm{C}$ and held at that temperature for another $24 \mathrm{hr}$ followed by drying the sample at $100^{\circ} \mathrm{C}$ for $12 \mathrm{hr}$ to

Polymers for Advanced Technology, Vol. 17, No. 4 (April 2006): pg. 312-319. DOI. This article is @ Wiley and permission has been granted for this version to appear in e-Publications@Marquette. Wiley does not grant permission for this article to be further copied/distributed or hosted elsewhere without the express permission from Wiley. 
drive off excess monomer. Pure PMMA was made in a similar fashion without the additive.

Powder X-ray diffraction (PXRD) patterns of the synthesized layered materials were obtained from a $2 \theta$ circle Rikagu diffractometer using $\mathrm{Cu}-\mathrm{K}_{\mathrm{a}}(\lambda=1.54 \AA)$ radiation source operated at $50 \mathrm{kV}$ and 20 $m A$, with data acquisition done in $2 \theta$ steps of $0.036^{\circ}$ per $20 \mathrm{sec}$.

Powdered samples were mounted on quartz slides using $10 \%(\mathrm{v} / \mathrm{v}) \mathrm{GE}$ 7031 epoxy in ethanol after it was found that the mounting process did not perturb the XRD patterns. Polymer composite samples were pressed into $1 \mathrm{~mm}$ thick platelets, which were then mounted onto vertically oriented sample holders for XRD analysis. Basal spacing of the synthesized clays and polymer composites were obtained from 00/ $(I=1-3)$ reflections after fitting the raw spectra to a pseudo-Voight XFIT ${ }^{33}$ program, stripping off the $\mathrm{Cu}-\mathrm{K}_{\mathrm{a} 2}$ contribution. Average crystallite sizes, $\tau$, were determined using the Debye-Scherrer equation:

$$
\tau=\kappa \lambda /\left(\beta_{\tau} \cos \theta\right)
$$

Where $K$ is a constant ( 0.9 for powders), ${ }^{34} \beta_{\tau}$ is the full width at halfmaximum height of the target diffraction peak of the material after correction for $\mathrm{Cu}-\mathrm{K}_{\mathrm{a} 2}$ and the instrumental broadening, and $\lambda$ is the $\mathrm{X}$ ray wavelength, $1.54 \AA$ for $\mathrm{Cu}-\mathrm{K}_{\mathrm{a} 1}$.

FT-IR spectra of the composites were determined using the $\mathrm{KBr}$ method on a Nicolet Magna-IR 560 spectrometer. FT-IR spectra were acquired at $1 \mathrm{~cm}^{-1}$ resolution, in the $400-4000 \mathrm{~cm}^{-1}$ region, averaging 40 scans. TGA and DTA were performed on a SDT 2960 simultaneous DTA-TGA instrument from 50 to $600^{\circ} \mathrm{C}$ using constant heating rates of $10,15,20$, and $25 \mathrm{~K} / \mathrm{min}$ in air, flowing at $85 \pm 5 \mathrm{ml} \mathrm{min}^{-1}$, with sample sizes of $21.0 \pm 1.0 \mathrm{mg}$ contained in aluminum cups. A Mattson-Cahn TG-131-TGA coupled to a FT-IR (TGA-FTIR) instrument was employed in this study to monitor the gases evolved during combustion processes. TGA-FTIR experiments were performed on $50 \pm$ $5 \mathrm{mg}$ samples that were heated between 50 and $600^{\circ} \mathrm{C}$ at $20^{\circ} \mathrm{C} \mathrm{min} \mathrm{m}^{-1}$ with air as the purge gas (flow rate, $85 \pm 5 \mathrm{ml} \mathrm{min}^{-1}$ ).

Polymers for Advanced Technology, Vol. 17, No. 4 (April 2006): pg. 312-319. DOI. This article is @ Wiley and permission has been granted for this version to appear in e-Publications@Marquette. Wiley does not grant permission for this article to be further copied/distributed or hosted elsewhere without the express permission from Wiley. 
NOT THE PUBLISHED VERSION; this is the author's final, peer-reviewed manuscript. The published version may be accessed by following the link in the citation at the bottom of the page.

PMMA composite samples $(30 \mathrm{~g})$ were compression molded into $10 \mathrm{~cm} \times 10 \mathrm{~cm}$ square plaques of uniform thickness $(\sim 2 \mathrm{~mm})$ before cone calorimetry was performed on an Atlas Cone 2 instrument, incident flux of $35 \mathrm{~kW} \mathrm{~m}^{-2}$. Bright field TEM images were collected at $60 \mathrm{kV}$ with a Zeiss 10c electron microscope at Cornell University.

\section{Results and Discussion}

The PXRD pattern of the $\mathrm{CHM}$ additive, $\mathrm{Cu}_{2}(\mathrm{OH})_{3}$ $\left(\mathrm{H}_{2} \mathrm{C}=\mathrm{C}\left(\mathrm{CH}_{3}\right) \mathrm{CO}_{2}\right) \cdot \mathrm{zH}^{2} \mathrm{O}$, is shown in trace (a) in Fig. 1(A). The XRD data exhibit similar features to isomorphic $\mathrm{Cu} 2(\mathrm{OH}) 3(\mathrm{CH} 3 \mathrm{CO} 2) \cdot z \mathrm{H} 2 \mathrm{O}$ which has been reported to have a botallackite-type structure. ${ }^{35}$ Using Bragg's equation, $\lambda=2 d \sin \theta$, and the 001 reflection, the basal spacing, $d$, is found to be $11.5 \AA$. No significant change in the $d$ spacing was observed for PMMA/CHM-4B made through bulk polymerization as shown in Fig. 1(A). The XRD patterns of $\mathrm{CHM}$ and PMMA/CHM-3, obtained on a different X-ray diffractometer (Cornell University), are shown in Fig. 1(B). After solution blending of the model compound, CHM, with PMMA in acetone, the basal spacing increased to $12.8 \AA$ indicating that the structure has been swelled as a result of sample preparation, suggesting some minor intercalation.

XRD alone cannot sufficiently characterize the nature of the dispersion of the additive in PMMA. TEM was employed to examine the microstructure of the PMMA/CHM-3 composite. TEM provides information about spatial distribution of the additive in a local area of the composite. Figure 2 shows TEM images for the PMMA/CHM-3 sample at both low and high magnification. The low magnification TEM image shows that $\mathrm{CHM}$ is fairly well distributed. Dark lines running approximately parallel to each other are clearly seen in the low magnification image. The average thickness of these dark lines is 458 $\pm 7 \AA$ corresponding to $36 \pm 1$ layers of the copper hydroxyl sheets stacked upon each other taking the basal spacing to be $12.8 \AA$ as calculated for PMMA/CHM-3. The crystallite size of $\mathrm{CHM}$ in the $c$-axis direction was calculated independently using the Debye-Scherrer equation to be $390 \pm 25 \AA$ corresponding to $34 \pm 3$ copper hydroxide layers stacked together. These data suggest that some of the $\mathrm{CHM}$ phase remains intact during polymerization. While the 001 peak in the $\mathrm{PMMA} / \mathrm{CHM}-3$ composite is narrower than for $\mathrm{CHM}$ itself, this effect cannot be attributed to particle size increase since mixed-layering and

Polymers for Advanced Technology, Vol. 17, No. 4 (April 2006): pg. 312-319. DOI. This article is @ Wiley and permission has been granted for this version to appear in e-Publications@Marquette. Wiley does not grant permission for this article to be further copied/distributed or hosted elsewhere without the express permission from Wiley. 
NOT THE PUBLISHED VERSION; this is the author's final, peer-reviewed manuscript. The published version may be accessed by following the link in the citation at the bottom of the page.

preferred orientations are known to perturb XRD measurements in organo-clay dispersions. ${ }^{36}$

The high magnification TEM image is consistent with neither delamination nor exfoliation. Nanoscale tactoids are observed but there is not enough evidence to suggest intercalation. This is consistent with a small increase in $d$ spacing from XRD, which suggest no meaningful intercalation. Even though XRD patterns and TEM images do not give conclusive evidence of nanocomposite formation via the routes typically observed for polymer/clay samples, the presence of nanometric crystallite sizes of $\mathrm{CHM}$ in at least one dimension suffices to describe PMMA/CHM-3 as a nanocomposite.

TGA curves showing the variation of undecomposed mass percentage as a function of temperature for pure PMMA, PMMA/CHM-0, and $\mathrm{PMMA} / \mathrm{CHM}-3$ are presented in Fig. 3(A). The thermal degradation of pure PMMA prepared by free radical polymerization is expected to show three stages of mass loss. ${ }^{26,37-39}$ The first stage of thermal degradation is initiated by scission of weak peroxide and hydroperoxide linkages mainly due to the combination of monomer with $\mathrm{O}_{2}$ during synthesis. ${ }^{40}$ Head-to-head $(\mathrm{H}-\mathrm{H})$ linkages from termination by combination are also easily broken at relatively low temperatures, leading to the production of free radicals, which will participate in the further depolymerization at higher temperatures through chain transfer processes. The second weight loss is largely a result of scission at the unsaturated ends due to termination by disproportionation. This process involves homolytic cleavage of the $\mathrm{C}-$ $C$ bond $\beta$ to the vinyl group while the last step is mainly due to the random chain scission of the PMMA backbone. ${ }^{38}$

From Fig. 3(A), commercial PMMA shows no weight loss at low temperatures $\left(<250^{\circ} \mathrm{C}\right)$ as is also evident in the corresponding derivatized thermal gravimetric analysis (DTG) plot of $\delta \alpha / \delta T$ versus temperature shown in Fig. 3(B). However, multiple overlapping weight losses are observed from approximately $250^{\circ} \mathrm{C}$ to $440^{\circ} \mathrm{C}$ for pure PMMA. This is consistent with a previous report of TGA of commercial PMMA with the same molecular weight. ${ }^{26}$ In contrast, for the recrystallized sample (PMMA/CHM-0), a significant $(\sim 10 \%)$ mass loss occurs at a lower temperature as compared to the commercial sample. TGA-FIR analysis confirms that this is due to the loss of acetone, the

Polymers for Advanced Technology, Vol. 17, No. 4 (April 2006): pg. 312-319. DOI. This article is (C Wiley and permission has been granted for this version to appear in e-Publications@Marquette. Wiley does not grant permission for this article to be further copied/distributed or hosted elsewhere without the express permission from Wiley. 
solvent used to prepare solution-blended samples. The first stage of weight loss for $\mathrm{PMMA} / \mathrm{CHM}-3$, begins at about $150^{\circ} \mathrm{C}$ and corresponds to the loss of the water and methacrylate from the additive as well as residual acetone. However, the remainder of the degradation pattern for PMMA/CHM-3 is significantly shifted to higher temperatures (see Fig. $3 \mathrm{~A}$ and $3 \mathrm{~B}$ ) suggesting that the polymeric composite is more thermally stable than the commercial PMMA and the PMMA/CHM-0 sample.

From Fig. 3(A), the temperatures at which 10, 50, and 90\% mass of the polymer composite are lost, $T_{10}, T_{50}, T_{90}$ are 33,45 , and $20^{\circ} \mathrm{C}$ higher for PMMA/CHM-3 than for PMMA/ CHM-0 respectively. Chen and coworkers reported a positive shift of $45^{\circ} \mathrm{C}$ in the $T_{50}$ value by modifying PMMA with 30 wt\% MgAl (dodecyl sulfate), a layered double hydroxide. ${ }^{41}$ However, such high loadings can significantly affect the mechanical properties of the composites in an undesirable way. The significant improvement in the threshold temperatures of PMMA/CHM-3 at 3\% loading is promising for development of this new class of additives.

Figure $4(A)$ shows TGA curves for pure PMMA and PMMA/CHM$4 \mathrm{~B}$ synthesized via bulk polymerization, with corresponding DTG plots provided in Fig. 4(B). Three stages of thermal decomposition are clearly seen for pure PMMA. The first stage in mass loss at about $200^{\circ} \mathrm{C}$ should correspond to depolymerization initiated by weak $\mathrm{H}-\mathrm{H}$ linkages together with weak peroxides and/or hydroperoxides linkages. ${ }^{40}$ However, this stage is insignificant, suggesting that there are few of the above-mentioned linkages. The second stage at about $300^{\circ} \mathrm{C}$ is a result of radical transfer to unsaturated chain ends while the last stage around $365^{\circ} \mathrm{C}$ corresponds to random scission. ${ }^{38}$ PMMA/CHM-4B shows a similar behavior except that the degradation temperatures at maximum weight loss for the three stages are shifted to higher values, implying improved thermal stability. The second and last stages of mass losses for pure PMMA in the DTG plots are substantial and equally important while for PMMA/CHM-4B the second mass loss $\left(\sim 300^{\circ} \mathrm{C}\right)$ is less pronounced than the last stage, which is also shifted to higher temperatures, $\left(\sim 390^{\circ} \mathrm{C}\right)$ relative to pure PMMA.

Figure 5(A) shows DTA curves for pure PMMA, PMMA/ CHM-0, and PMMA/CHM-3 composite. The DTA curves are shown to draw a

Polymers for Advanced Technology, Vol. 17, No. 4 (April 2006): pg. 312-319. DOI. This article is (C Wiley and permission has been granted for this version to appear in e-Publications@Marquette. Wiley does not grant permission for this article to be further copied/distributed or hosted elsewhere without the express permission from Wiley. 
NOT THE PUBLISHED VERSION; this is the author's final, peer-reviewed manuscript. The published version may be accessed by following the link in the citation at the bottom of the page.

comparison between thermal degradation behaviors of pure PMMA and $\mathrm{PMMA} / \mathrm{CHM}-0$ to that of the polymer composite, PMMA/CHM-3. The DTA curves for pure PMMA and PMMA/CHM-0 show similar behavior throughout the decomposition process. Three endotherms are seen around 270,330 , and $380^{\circ} \mathrm{C}$ while one exotherm is observed at about $420^{\circ} \mathrm{C}$. In contrast, the PMMA/CHM-3 composite shows an exotherm around $280^{\circ} \mathrm{C}$ (possibly due to oxidation of organic interlayer species) followed by an endotherm at about $330^{\circ} \mathrm{C}$ similar to the reference samples.

The second endothermic process for PMMA/CHM-3 occurs at a slightly higher temperature, $390^{\circ} \mathrm{C}$, as compared to about $380^{\circ} \mathrm{C}$ for the reference samples consistent with improved thermal stability of the composite. The last exothermic process for the composite is slightly shifted to a higher temperature but is of similar magnitude to pure PMMA, and PMMA/CHM-0. This suggests that the mass losses at higher conversion fractions in both the reference materials and the composite are due to the same basic mechanism.

Figure 5(B) shows DTA curves for pure PMMA and PMMA/CHM4B composite synthesized via bulk polymerization. The DTA curve for pure PMMA shows two overlapping endotherms starting at 250 to $420^{\circ} \mathrm{C}$ and a small exothermic feature at $430^{\circ} \mathrm{C}$. However, three endotherms are seen at around 265,300 , and $400^{\circ} \mathrm{C}$ for PMMA/CHM$4 \mathrm{~B}$. An exotherm at around $250^{\circ} \mathrm{C}$ is due to the thermal degradation of interlayer organic species contained in the additive. An exothermic process at $430^{\circ} \mathrm{C}$ in the $\mathrm{PMMA} / \mathrm{CHM}-4 \mathrm{~B}$ sample is enhanced relative to that observed for the pure PMMA. This suggests that a significant mass loss occurs at elevated temperatures for the composite material, mainly due to random chain scission. The notable difference in the DTA curves for pure PMMA and PMMA/CHM-4B might suggest a change in the relative contribution of the different degradation processes for these polymeric materials. Further work is required to test this hypothesis.

Thermogravimetric measurements provide a qualitative means of estimating the thermal stability of polymeric materials. ${ }^{42,43}$ Thermal stability is defined here as the onset temperature for degradation and the rate of degradation of the respective materials. As noted earlier, the thermal degradation of PMMA and PMMA/CHM composites involves

Polymers for Advanced Technology, Vol. 17, No. 4 (April 2006): pg. 312-319. DOI. This article is (C Wiley and permission has been granted for this version to appear in e-Publications@Marquette. Wiley does not grant permission for this article to be further copied/distributed or hosted elsewhere without the express permission from Wiley. 
multiple degradation steps. A simple means of extracting effective kinetic parameters from these rather complicated decomposition processes is analysis of multiple heating rate kinetics (MHRKs), applying the commonly used Flynn-Wall-Ozawa ${ }^{44,45}$ method specifically derived for heterogeneous chemical reactions under linear heating rates. The Flynn-Wall-Ozawa method is expressed by the equation:

$$
\log f(x)=\log \left(\frac{A E_{\mathrm{a}}}{R}\right)-\log (\beta)-2.315-\frac{0.456 E_{a}}{R T}
$$

Where $f(x)$ is known as the conversional functional relationship; $A$ is the pre-exponential factor (in $\min ^{-1}$ ),$E_{a}$ is the apparent activation energy (in $\mathrm{kJ} \mathrm{mol}^{-1}$ ), $R$ is the gas constant, $\beta$ is the heating rate (in $\mathrm{K}$ $\min -1$ ), and $T$ is the absolute temperature (in $\mathrm{K}$ ).

The $E_{a}$ values for the virgin PMMA, PMMA/CHM-0, PMMA/CHM-3, bulk polymerized pure PMMA, and PMMA/CHM-4B were calculated from slopes of the isoconversional plots of $\log (\beta)$ versus $1 / T$. The $E_{a}$ values were calculated for fractional conversions $\alpha=0.05-0.90$ at intervals of 0.05. These values are plotted in Fig. 6(A) and 6(B). The value for the pure commercial PMMA, as received, decreased from 160 to $110 \mathrm{~kJ}$ $\mathrm{mol}^{-1}$ between and 0.55 . The value then increased in a parabolic fashion to a value of $180 \mathrm{~kJ} \mathrm{~mol}^{-1}$ at $\alpha=0.9$. Laachachi et al. reported similar results for the thermal degradation of PMMA in air. ${ }^{37}$ The observed apparent $E_{a}$ value for the PMMA/CHM-3 increased with conversion to reach a constant $E_{a}$ value of $\sim 187 \mathrm{~kJ} \mathrm{~mol}^{-1}$ from until the end of the reaction. For decomposition via a single step, the MHRKs are expected to result in constant values as a function of $\alpha^{45}$. Multistep processes, such as those observed here, may result in variations in $E_{a}$ values over the conversion range, however, unambiguous interpretation of such changes is difficult. There is no significant difference, within experimental error, between the $E_{a}$ value for $\mathrm{PMMA} / \mathrm{CHM}-0$, and PMMA/CHM- 3 in the region, $\alpha=0.05$ to 0.40 . Both samples show higher $E_{a}$ values than the commercial sample at low temperatures/conversions. However, the complicated nature of mass loss at the earlier degradation stages, particularly in the solution blended samples where solvent loss is occurring, precludes attributing $E_{a}$ differences at low conversions to significant changes in polymer

Polymers for Advanced Technology, Vol. 17, No. 4 (April 2006): pg. 312-319. DOI. This article is (C) Wiley and permission has been granted for this version to appear in e-Publications@Marquette. Wiley does not grant permission for this article to be further copied/distributed or hosted elsewhere without the express permission from Wiley. 
stability without additional experimental characterization of degradation products.

A difference of $>50 \mathrm{~kJ} \mathrm{~mol}^{-1}$ between the $\mathrm{E}_{\mathrm{a}}$ value of PMMA/CHM-0 and PMMA/CHM-3, $(\alpha=0.5-0.9)$ is, however, consistent with the suggestion that the thermal stability of PMMA is greatly enhanced by addition of the LHS, CHM. Similar trends in the $E_{a}$ values are seen for the samples prepared via bulk polymerization. In contrast to results obtained through solution blending, the $E_{a}$ values at specific fractional conversions, $\alpha$, is always higher for PMMA/CHM4B than for pure PMMA. Differences of $>30 \mathrm{~kJ} \mathrm{~mol}^{-1}$ in for PMMA/CHM-4B relative to pure PMMA are seen for $\alpha=0.55-0.9$. However, the general shapes of $E_{a}$ curves as a function of $\alpha$ are similar for the two preparative methods, suggesting that there is no significant change in the degradation mechanism of composites made from solution blending as compared to those made via bulk polymerization. In both cases the elevated $E_{a}$ values correlate, as expected, with the observed improved thermal stability of the polymer composites seen in TGA profiles acquired at a single heating rate.

The positive shift in maximum mass-loss temperature for PMMA/CHM-3 implies that the presence of the LHS in the polymer matrix severely limits or prevents depolymerization processes by radical chain transfer (second stage). A greater portion of the polymer composite is then lost through random scission occurring at elevated temperatures. This might be as a result of the formation of organic/ inorganic networks, such as $\mathrm{Cu}$ salt ionomers that are thermally more stable than PMMA. ${ }^{46}$ In addition these networks may serve to prevent the rapid diffusion of free radicals, which are known to promote the depolymerization process. ${ }^{47}$ Also, the presence of the inorganic moieties may serve to stabilize or even trap free radicals by participation in redox reactions as previously hypothesized in the authors' laboratory with HDS and LHS/PMMA composites. ${ }^{21}$

In previous work, ${ }^{21}$ differences in copper oxidation states in cone residues were observed for composites made with $\mathrm{CHM}$ and a zinc/copper methracrylate HDS. In order to further explore the evolution of copper oxidation states, the PMMA-CHM-4B and pure $\mathrm{CHM}$ were heated for TGA at $20^{\circ} \mathrm{C} \mathrm{min}^{-1}$ and the resulting residues were analyzed via XRD. The presence of Cu(I) oxide (PDF\# 35-1091) ${ }^{48}$ in 
the residue of $\mathrm{PMMA} / \mathrm{CHM}-4 \mathrm{~B}$ after heating to $250^{\circ} \mathrm{C}$ is observed in the XRD pattern shown in trace (c) of Fig. 1(A). Cu(I) oxide and $\mathrm{Cu}$ metal (PDF\# 4-836) ${ }^{48}$ were seen in the XRD pattern of the pure CHM residue after heating to $270^{\circ} \mathrm{C}$. The absence of metallic $\mathrm{Cu}$ in the residue of PMMA/CHM-4B at similar temperature suggests that the products of degradation of PMMA may participate in redox reactions with the additive.

$\mathrm{Cu}$ (II), in the form of $\mathrm{CuCl}_{2}$, has been reported ${ }^{49}$ to have a stabilizing effect on the thermal degradation of PMMA, while $\mathrm{Cu}(\mathrm{I})$ $(\mathrm{CuCl})$ did not have any effect on the thermal degradation of PMMA in air. However, several authors have shown that $\mathrm{Cu}(\mathrm{I})$ based catalysts can be used in the polymerization of PMMA through atom transfer radical polymerization (ATRP) with high efficiency. ${ }^{50-52}$ The presence of $\mathrm{Cu}(\mathrm{I})$ ions at temperatures as low as $250^{\circ} \mathrm{C}$ could establish conditions suitable for living polymerization through radical, MMA · , combination. This could lead to retardation of the depolymerization process as more polymer chains are generated concomitant with the combustion of the starting material. Therefore, the presence of $\mathrm{Cu}$ ions in the polymeric matrix during combustion may serve to stabilize the composite materials, consistent with the enhanced TGA residue reported previously for $\mathrm{CHM}$ additives with PMMA. ${ }^{21}$ Analysis of PMMA/CHM residues to test this hypothesis will be the subject of future work.

The potential effect of additive on the extent of initial polymerization during sample preparation must also be considered, particularly for the bulk polymerized samples. Kashiwagi et al. ${ }^{38}$ have suggested that a difference in the molecular weights of polymers synthesized via bulk polymerization will affect their degradation profiles. The presence of a $\mathrm{Cu}(\mathrm{II})$-based additive in PMMA/CHM-4B could have an effect on its average molecular weight as compared to pure PMMA. Polymers with fewer unsaturated chain ends would lose less mass in the second degradation stage. To rule out the possibility of having significantly different molecular weights in pure PMMA compared to PMMA/CHM-4B FT-IR analysis was performed for the bulk polymerized samples and the results are presented in Fig. 7. As reported by Suske et al. ${ }^{53}$ comparison of the integrated intensities of the $\mathrm{C}-\mathrm{H}$ stretching bands at about $3000 \mathrm{~cm}^{-1}$ to the $\mathrm{C}=\mathrm{O}$ antisymmetric stretch at around $1730 \mathrm{~cm}^{-1}$ can be used to estimate the extent of crosslinking in PMMA. More highly crosslinked samples have

Polymers for Advanced Technology, Vol. 17, No. 4 (April 2006): pg. 312-319. DOI. This article is (C Wiley and permission has been granted for this version to appear in e-Publications@Marquette. Wiley does not grant permission for this article to be further copied/distributed or hosted elsewhere without the express permission from Wiley. 
lower $\mathrm{C}-\mathrm{H} / \mathrm{C}=\mathrm{O}$ ratios. Based on the data shown in Fig. 7, the $\mathrm{C}$ $\mathrm{H} / \mathrm{C}=\mathrm{O}$ ratios were found to be $0.74 \pm 0.06$ and $0.78 \pm 0.06$ for PMMA and $\mathrm{PMMA} / \mathrm{CHM}-4 \mathrm{~B}$ respectively, suggesting that there is no significant difference in crosslinking due to the presence of the CHM additive.

Cone calorimetry experiments were performed to investigate the relative flammability of PMMA/CHM-0 to PMMA/CHM-3. Figure 8 shows the variation of heat released with combustion time for the commercial PMMA, PMMA/CHM-0, and PMMA/CHM-3. The THR as depicted by the integrated areas under the respective heat release rate versus time

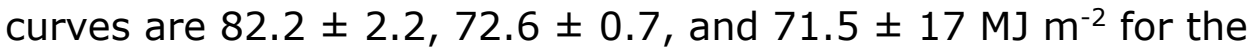
commercial PMMA, PMMA/CHM-0, and PMMA/CHM-3 respectively. Even though there is a significant reduction in the THR for the recrystallized polymer composites relative to the commercial PMMA, there is, however, no meaningful difference between $\mathrm{PMMA} / \mathrm{CHM}-0$ and PMMA/CHM-3.

The obtained kinetic information (activation energies) used to estimate the thermal stability of these polymeric materials is derived from weight loss profiles of thermal degradation processes. The mathematical function used to describe the degradation process is modeled for the released products, i.e., from weight loss, and provides no information about which, or how many bonds are broken at any given conversion fraction. ${ }^{54}$ The extracted effective $E_{a}$ values are thus useful here to explain the shift to higher threshold temperatures for PMMA/CHM-3 but not necessarily its flammability. While TGA curves and apparent $E_{a}$ values suggest a significant improvement in the thermal stability of PMMA/CHM-3 relative to PMMA/CHM-0, cone calorimetry measurements suggest no difference in their flammability.

\section{Conclusions}

CHM has been used as an additive to provide thermal stability to PMMA. Solution blending and bulk polymerization in the presence of 3$4 \%$ by mass of the additive result in a significant shift in the temperature for $50 \%$ mass loss. Apparent $E_{a}$ values were significantly higher for the PMMA/CHM-3 composite a difference $>50 \mathrm{~kJ} \mathrm{~mol}^{-1}$ ) for the later stages of the thermal decomposition process $(\alpha=0.5-0.9)$ compared to the reference sample PMMA/CHM-0. A similar trend was observed for PMMA/CHM-4B with values for the composite being $30 \mathrm{~kJ}$

Polymers for Advanced Technology, Vol. 17, No. 4 (April 2006): pg. 312-319. DOI. This article is (C Wiley and permission has been granted for this version to appear in e-Publications@Marquette. Wiley does not grant permission for this article to be further copied/distributed or hosted elsewhere without the express permission from Wiley. 
$\mathrm{mol}^{-1}$ greater than the pure PMMA in the region $\alpha=0.55-0.9$. However, in contrast to bulk polymerized samples, no significant difference was observed in the THR in cone calorimetry measurements for the solution blended composite, PMMA/CHM-3, relative to PMMA/CHM-O.

\section{Acknowledgments}

The authors thank Marquette University Committee on Research for financial assistance and Charles A. Wilkie and coworkers at Marquette University for fruitful discussions.

\section{References}

1. Huang X, Brittain WJ. Synthesis and characterization of PMMA nanocomposites by suspension and emulsion polymerization. Macromolecules 2001; 34: 3255-3260.

2. Qu X, Guan T, Liu G, She Q, Zhang L. Preparation, structural characterization, and properties of poly(methyl methacrylate)/montmorillonite nanocomposites by bulk polymerization. J. Appl. Polym. Sci. 2005; 97: 348-357.

3. Hwu JM, Jiang GJ, Gao ZM, Xie W, Pan WP. The characterization of organic modified clay and clay-filled PMMA nanocomposite. J. Appl. Polym. Sci. 2002; 83: 1702-1710.

4. Yang F, Nelson GL. PMMA/silica nanocomposite studies: synthesis and properties. J. Appl. Polym. Sci. 2004; 91: 3844- 3850.

5. Lee DC, Jang LW. Preparation and characterization of PMMA-clay hybrid composite by emulsion polymerization. J. Appl. Polym. Sci. 1996; 61: 1117-1122.

6. Shen Z, Simon GP, Cheng Y-B. Nanocomposites of poly(methyl methacrylate) and organically modified layered silicates by melt intercalation. J. Appl. Polym. Sci. 2004; 92: 2101-2115.

7. Kumar S, Jog JP, Natarajan U. Preparation and characterization of poly(methyl methacrylate)-clay nanocomposites via melt intercalation: the effect of organoclay on the structure and thermal properties. $J$. Appl. Polym. Sci. 2003; 89: 1186-1194.

8. Aymonier C, Bortzmeyer D, Thomann R, Mulhaupt R. Poly(methyl methacrylate)/palladium nanocomposites: synthesis and

Polymers for Advanced Technology, Vol. 17, No. 4 (April 2006): pg. 312-319. DOI. This article is @ Wiley and permission has been granted for this version to appear in e-Publications@Marquette. Wiley does not grant permission for this article to be further copied/distributed or hosted elsewhere without the express permission from Wiley. 
characterization of the morphological, thermomechanical, and thermal properties. Chem. Mater. 2003; 15: 4874-4878.

9. Zhu J, Morgan AB, Lamelas FJ, Wilkie CA. Fire properties of polystyreneclay nanocomposites. Chem. Mater. 2001; 13: 3774-3780.

10. Laachachi A, Leroy E, Cochez M, Ferriol M, Lopez Cuesta JM. Use of oxide nanoparticles and organoclays to improve thermal stability and fire retardancy of poly(methyl methacrylate). Polym. Degrad. Stab. 2005; 89: 344-352.

11. Bourbigot S, Gilman JW, Wilkie CA. Kinetic analysis of the thermal degradation of polystyrene-montimorillonite nanocomposite. Polym. Degrad. Stab. 2004; 84: 483-492.

12. Mallikarjuna NN, Venkataraman A, Aminabhavi TM. A study on $\quad \gamma$ - $\mathrm{Fe}_{2} \mathrm{O}_{3}$ loaded poly(methyl methacrylate) nanocomposites. J. Appl. Polym. Sci. 2004; 94: 2551-2554.

13. Yeh J-M, Liou S-J, Lai M-C, Chang Y-W, Huang C-Y, Chen C-P, Jaw J-H, Tsai T-Y, Yu Y-H. Comparative studies of the properties of poly(methyl methacrylate)-clay nanocomposite materials prepared by in situ emulsion polymerization and solution dispersion. J. Appl. Polym. Sci. 2004; 94: 1936-1946.

14. Yeh J-M, Liou S-J, Lin C-Y, Cheng C-Y, Chang Y-W. Anticorrosively enhanced PMMA-clay nanocomposite materials with quaternary alkylphosphonium salt as an intercalating agent. Chem. Mater. 2002; 14: $154-161$

15. Kashiwagi $T$, Morgan AB, Antonucci JM, VanLandingham MR, Harris RH, Awad $\mathrm{WH}$, Shields JR. Thermal and flammability properties of a silicapoly(methyl methacrylate) nanocomposite. J. Appl. Polym. Sci. 2003; 89: 2072-2078.

16. Rajamathi M, Thomas GS, Kamath PV. The many ways of making anionic clays. Proc. Indian Acad. Sci., Chem. Sci. 2001; 113: 671-680.

17. Chandrasiri JA, Wilkie CA. Thermal degradation of poly(methyl methacrylate) in the presence of tin(IV) chloride and tetraphenyltin. Polym. Degrad. Stab. 1994; 45: 91-96.

18. Wang D, Zhu J, Yao Q, Wilkie CA. A comparison of various methods for the preparation of polystyrene and poly(methyl methacrylate) clay nanocomposites. Chem. Mater. 2002; 14: 3837-3843.

Polymers for Advanced Technology, Vol. 17, No. 4 (April 2006): pg. 312-319. DOI. This article is @ Wiley and permission has been granted for this version to appear in e-Publications@Marquette. Wiley does not grant permission for this article to be further copied/distributed or hosted elsewhere without the express permission from Wiley. 
NOT THE PUBLISHED VERSION; this is the author's final, peer-reviewed manuscript. The published version may be accessed by following the link in the citation at the bottom of the page.

19. Du J, Zhu J, Wilkie CA, Wang J. An XPS investigation of thermal degradation and charring on PMMA clay nanocomposites. Polym. Degrad. Stab. 2002; 77: 377-381.

20. Su S, Wilkie CA. Exfoliated poly(methyl methacrylate) and polystyrene nanocomposites occur when the clay cation contains a vinyl monomer. J. Polym. Sci., Part A: Polym. Chem. 2003; 41: 1124-1135.

21. Kandare E, Hall D, Jiang DD, Hossenlopp JM. Development of new fire retardant additives based on hybrid inorganic/ organic nanodimensional layered compounds: thermal degradation of PMMA composites. ACS Symposium Series 922, Fire and Polymers IV: Materials and Concepts for Hazard Prevention. Wilkie CA, Nelson GL (eds), American Chemical Society: Washington, DC, 2006; 131-143.

22. Beecroft LL, Ober CK. Nanocomposite materials for optical applications. Chem. Mater. 1997; 9: 1302-1317.

23. Sidorov SN, Volkov LV, Davankov VA, Tsyurupa MP, Valetsky PM, Bronstein LM, Karlinsey R, Zwanziger JW, Matveeva VG, Sulman EM, Lakina NV, Wilder EA, Spontak RJ. Platinum-containing hyper-crosslinked polystyrene as a modifier-free selective catalyst for L-sorbose oxidation. J. Am. Chem. Soc. 2001; 123: 10502-10510.

24. Landry CJT, Coltrain BK, Landry MR, Fitzgerald JJ, Long VK. poly(viny1 acetate)/silica filled materials: material properties of in situ vs fumed silica particles. Macromolecules 1993; 26: 3702-3712.

25. Jellinek HHG, Luh MD. Thermal degradation of isotactic and syndiotactic poly(methyl methacrylate). J. Phys. Chem. 1996; 70: 3672-3680.

26. Ferriol M, Gentilhomme A, Cochez M, Oget N, Mieloszynski JL. Thermal degradation of poly(methyl methacrylate) (PMMA): modelling of DTG and TG curves. Polym. Degrad. Stab. 2003; 79: 271-281.

27. Gao Z, Kaneko T, Hou D, Nakada M. Kinetics of thermal degradation of poly(methyl methacrylate) studied with the assistance of the fractional conversion at the maximum reaction rate. Polym. Degrad. Stab. 2004; 84: 399-403.

28. Hu Y-H, Chen $\mathrm{C}-\mathrm{Y}$. The effect of end groups on the thermal degradation of poly(methyl methacrylate). Polym. Degrad. Stab. 2003; 82: 81-88.

29. Hu Y-H, Chen C-Y. Study of the thermal behavior of poly(methyl methacrylate) initiated by lactams and thiols. Polym. Degrad. Stab. 2003; 80: 1-10.

Polymers for Advanced Technology, Vol. 17, No. 4 (April 2006): pg. 312-319. DOI. This article is @ Wiley and permission has been granted for this version to appear in e-Publications@Marquette. Wiley does not grant permission for this article to be further copied/distributed or hosted elsewhere without the express permission from Wiley. 
NOT THE PUBLISHED VERSION; this is the author's final, peer-reviewed manuscript. The published version may be accessed by following the link in the citation at the bottom of the page.

30. Peterson JD, Vyazovkin S, Wight CA. Kinetic study of stabilizing effect of oxygen on thermal degradation of poly(metyl methacrylate). J. Phys. Chem. B. 1999; 103: 8087-8092.

31. Holland BJ, Hay JN. The kinetics and mechanisms of the thermal degradation of poly(methyl methacrylate) studied by thermal analysisFourier transform infrared spectroscopy. Polymer 2001; 42: 48254835.

32. Jimenez-Lopez A, Rodriguez-Castellon E, Olivera-Pastor P, Maireles-Torres $\mathrm{P}$, Tomlinson AAG, Jones DJ, Roziere J. Layered basic copper anion exchangers: chemical characterization and X-ray absorption study. J. Mater. Chem. 1993; 3: 303-307.

33. Cheary RW, Coelho AA. Programs XFIT and FOURYA, deposited in CCP14. Powder Diffraction Library, Engineering and Physical Sciences Research Council, Daresbury Laboratory, Warrington. http://www.ccp14.ac.uk/tutorial/xfit-95/xfit.htm 1996.

34. Jenkins R, Synder RL. Introduction to X-ray Powder Diffractometry. Wiley: New York, 1996.

35. Yamanaka S, Sako T, Seki K, Hattori M. Anion exchange reactions in layered basic copper salts. Solid State Ionics 1992; 53-56: 527-533.

36. Eckel DF, Balogh MP, Fasulo PD, Rodgers WR. Assessing organo-clay dispersion in polymer nanocomposites. J. Appl. Polym. Sci. 2004; 93: 1110-1117.

37. Laachachi A, Cochez M, Ferriol M, Leroy E, Lopez Cuesta JM, Oget N. Influence of $\mathrm{Sb}_{2} \mathrm{O}_{3}$ particles as filler on the thermal stability and flammability properties of poly(methyl methacrylate) (PMMA). Polym. Degrad. Stab. 2004; 85: 641-646.

38. Kashiwagi T, Inaba A, Brown JE, Hatada K, Kitayama T, Masuda E. Effects of weak linkages on the thermal and oxidative degradation of poly(methy1 methacrylates). Macromolecules 1986; 19: 2160-2168.

39. Laachachi $A$, Cochez M, Ferriol M, Lopez Cuesta JM, Leroy E. Influence of $\mathrm{TiO}_{2}$ and $\mathrm{Fe}_{2} \mathrm{O}_{3}$ fillers on the thermal properties of poly(methyl methacrylate) (PMMA). Mater. Lett. 2005; 59: 36-39.

40. Holland BJ, Hay JN. The effect of polymerization conditions on the kinetics and mechanisms of thermal degradation of PMMA. Polym. Degrad. Stab. 2002; 77: 435-439.

41. Chen W, Feng L, Qu B. In situ synthesis of poly(methyl methacrylate)/MgAl layered double hydroxide nanocomposite with high

Polymers for Advanced Technology, Vol. 17, No. 4 (April 2006): pg. 312-319. DOI. This article is @ Wiley and permission has been granted for this version to appear in e-Publications@Marquette. Wiley does not grant permission for this article to be further copied/distributed or hosted elsewhere without the express permission from Wiley. 
NOT THE PUBLISHED VERSION; this is the author's final, peer-reviewed manuscript. The published version may be accessed by following the link in the citation at the bottom of the page.

transparency and enhanced thermal properties. Solid State Commun. 2004; 130: 259-263.

42. Vyazovkin S, Wight CA. Isothermal and nonisothermal reaction kinetics in solids: in search of ways toward consensus. J. Phys. Chem. A. 1997; 101: 8279-8284.

43. Khawam A, Flanagan DR. Complementary use of model-free and modelistic methods in the analysis of solid-state kinetics. J. Phys. Chem. B. 2005; 109: 10073-10080.

44. Ozawa T. A new method of analyzing thermogravimetric data. Bull. Chem. Soc. Jpn 1965; 38: 1881-1886.

45. Vyazovkin S. Evaluation of activation energy of thermally stimulated solid-state reactions under arbitrary variation of temperature. J. Comp. Chem. 1997; 18: 393-402.

46. Kosyanchuk LF, Lipatova TE, Vilensky VA, Lipatov YS, Shtompel VI. Polyurethanes crosslinked by metals and their complexes with crown ether. J. Polym. Sci., Part A: Polym. Chem. 1998; 36: 1379-1386.

47. Wang $\mathrm{H}$, Xu P, Zhong W, Shen L, Du Q. Transparent poly(methyl methacrylate)/silica/zirconia nanocomposites with excellent thermal stabilities. Polym. Degrad. Stab. 2005; 87: 319-327.

48. Powder Diffraction File Alphabetical Indexes. Inorganic Phases. JCPDS, International Centre for Diffraction Data, Swartmore, PA, 1999.

49. Chandrasiri JA, Roberts DE, Wilkie CA. The effect of some transition metal chlorides on the thermal degradation of poly (methyl methacrylate): a study using TGA-FTIR spectrometry. Polym. Degrad. Stab. 1994; 45: 97-101.

50. Darcos V, Monge S, Haddleton DM. In situ Fourier transform near infrared spectroscopy monitoring of copper mediated living radical polymerization. J. Polym. Sci., Part A: Polym. Chem. 2004; 42: 49334940.

51. Miura Y, Satoh T, Narumi A, Nishizawa O, Okamoto Y, Kakuchi T. Atom transfer radical polymerization of methyl methacrylate in fluoroalcohol: simultaneous control of molecular weight and tacticity. Macromolecules 2005; 38: 1041-1043.

52. Percec V, Asandei AD, Asgarzadeh F, Bera TK, Barboiu B. $\mathrm{Cu}^{\mathrm{I}}$ and $\mathrm{Cu}^{\mathrm{II}}$ salts of group VIA elements as catalysts for living radical polymerization initiated with sulfonyl chlorides. J. Polym. Sci., Part A: Polym. Chem. 2000; 38: 3839-3843.

Polymers for Advanced Technology, Vol. 17, No. 4 (April 2006): pg. 312-319. DOI. This article is @ Wiley and permission has been granted for this version to appear in e-Publications@Marquette. Wiley does not grant permission for this article to be further copied/distributed or hosted elsewhere without the express permission from Wiley. 
NOT THE PUBLISHED VERSION; this is the author's final, peer-reviewed manuscript. The published version may be accessed by following the link in the citation at the bottom of the page.

53. Suske E, Scharf T, Krebs H-U, Panchenko E, Junkers T, Egorov M, Buback $\mathrm{M}$, Kijewski $\mathrm{H}$. Tuning of cross-linking and mechanical properties of laser-deposited poly(methyl methacrylate) films. J. Appl. Phys. 2005; 97: 63501-63504.

54. Maciejewski M. Thermal analysis and kinetic concepts of solid-state reactions. J. Therm. Anal. 1988; 33: 1269-1277.

\section{About the Authors}

Jeanne M. Hossenlopp : Department of Chemistry, Marquette University, P. O. Box 1881, Milwaukee, WI 53201-1881, USA.

Email : Jeanne.Hossenlopp@marquette.edu 
NOT THE PUBLISHED VERSION; this is the author's final, peer-reviewed manuscript. The published version may be accessed by following the link in the citation at the bottom of the page.

\section{Figure 1}
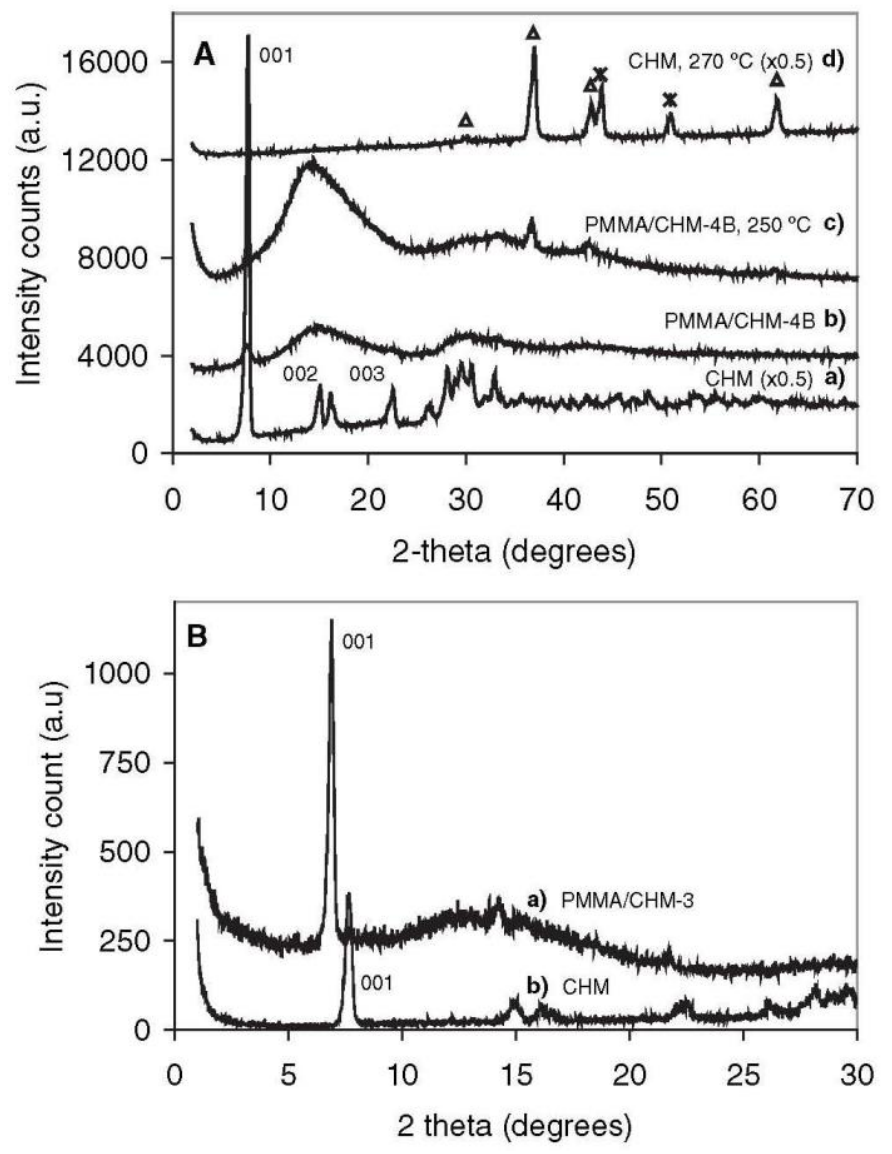

(A) XRD pattern of: (a) additive, CHM (scaled by a factor of 0.5 ); (b) PMMA/CHM-4B composite; (c) residue after heating PMMA/CHM-4B to $250^{\circ} \mathrm{C}$; (d) residue after heating $\mathrm{CHM}$ to $270^{\circ} \mathrm{C}$ at $20^{\circ} \mathrm{C} \mathrm{min-1}$ (scaled by a factor of 0.5 ), assignment of CuO $(\Delta)$ and $\mathrm{Cu}^{0}(*)$ reflections is indicated. Data are offset for clarity.

(B) XRD pattern of: (a) PMMA/CHM-3; (b) the additive, CHM. The XRD patterns in Fig. $1(B)$ were collected at Cornell University using a different instrument than used for patterns in Fig. 1(A). 
NOT THE PUBLISHED VERSION; this is the author's final, peer-reviewed manuscript. The published version may be accessed by following the link in the citation at the bottom of the page.

\section{Figure 2}
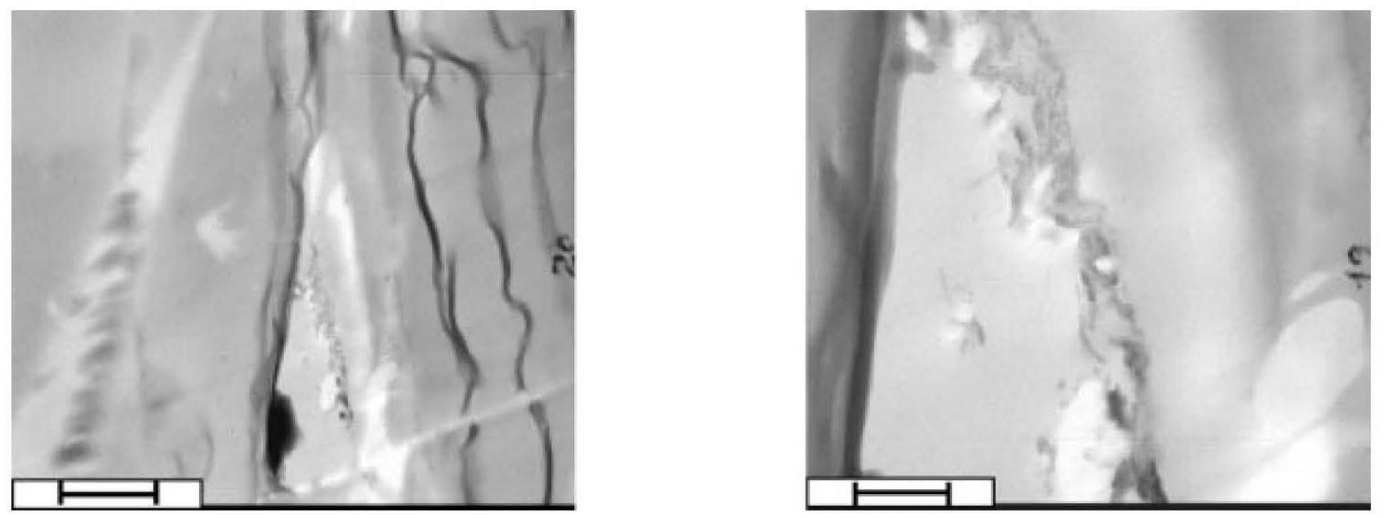

TEM images at low (left) and high (right) magnification for PMMA/CHM-3. For low magnification, the scale bar (bottom left) represents $500 \mathrm{~nm}$ while for high magnification, the scale bar (bottom left) represents $100 \mathrm{~nm}$. 
NOT THE PUBLISHED VERSION; this is the author's final, peer-reviewed manuscript. The published version may be accessed by following the link in the citation at the bottom of the page.

\section{Figure 3}

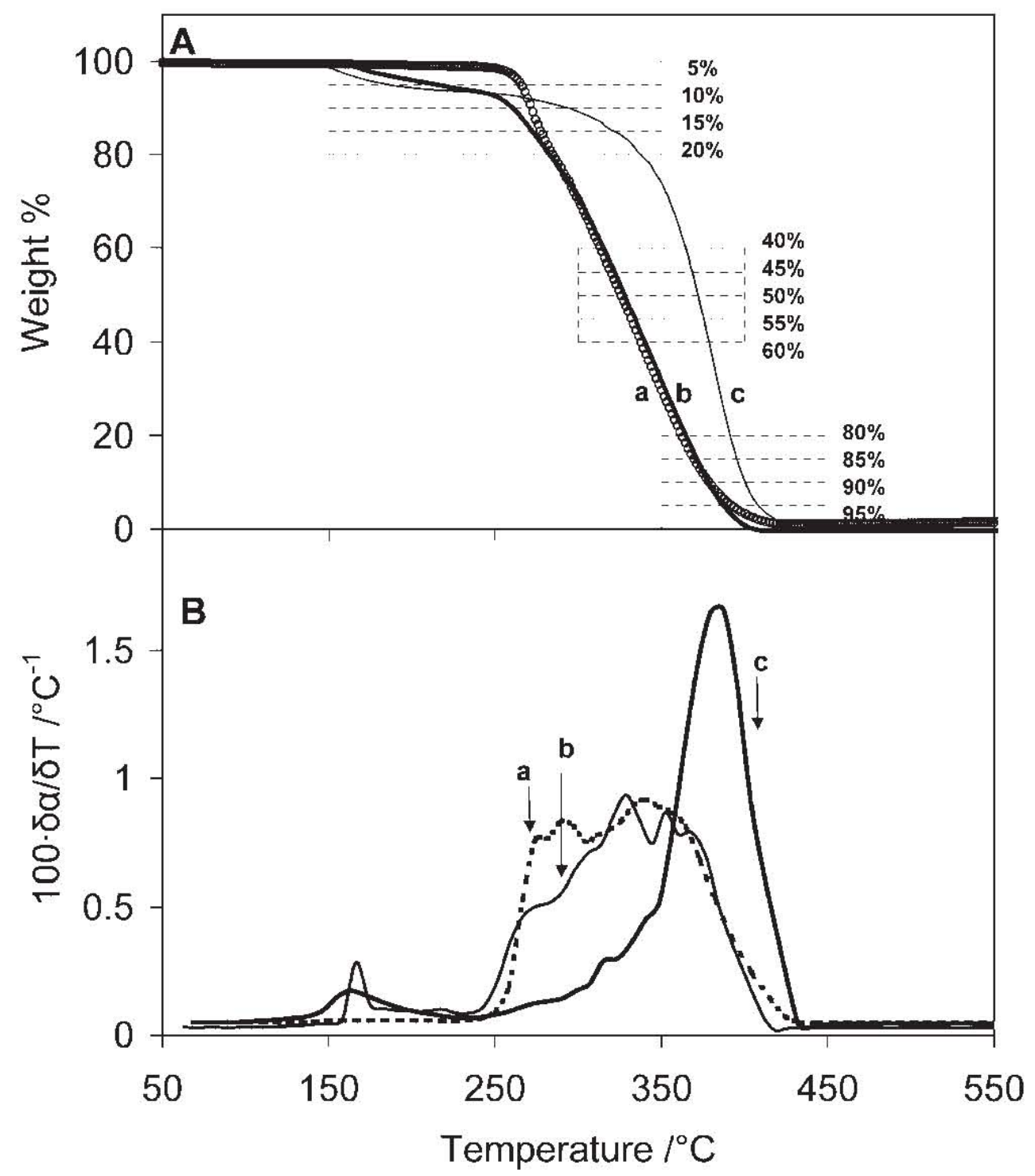

(A) TGA curves for: (a) commercial PMMA (O); (b) PMMA/CHM-0; (c) PMMA/CHM-3 composite.

(B) DTG curves for: (a) commercial PMMA; (b) PMMA/CHM-0; (c) PMMA/CHM-3 composite. 


\section{Figure 4}

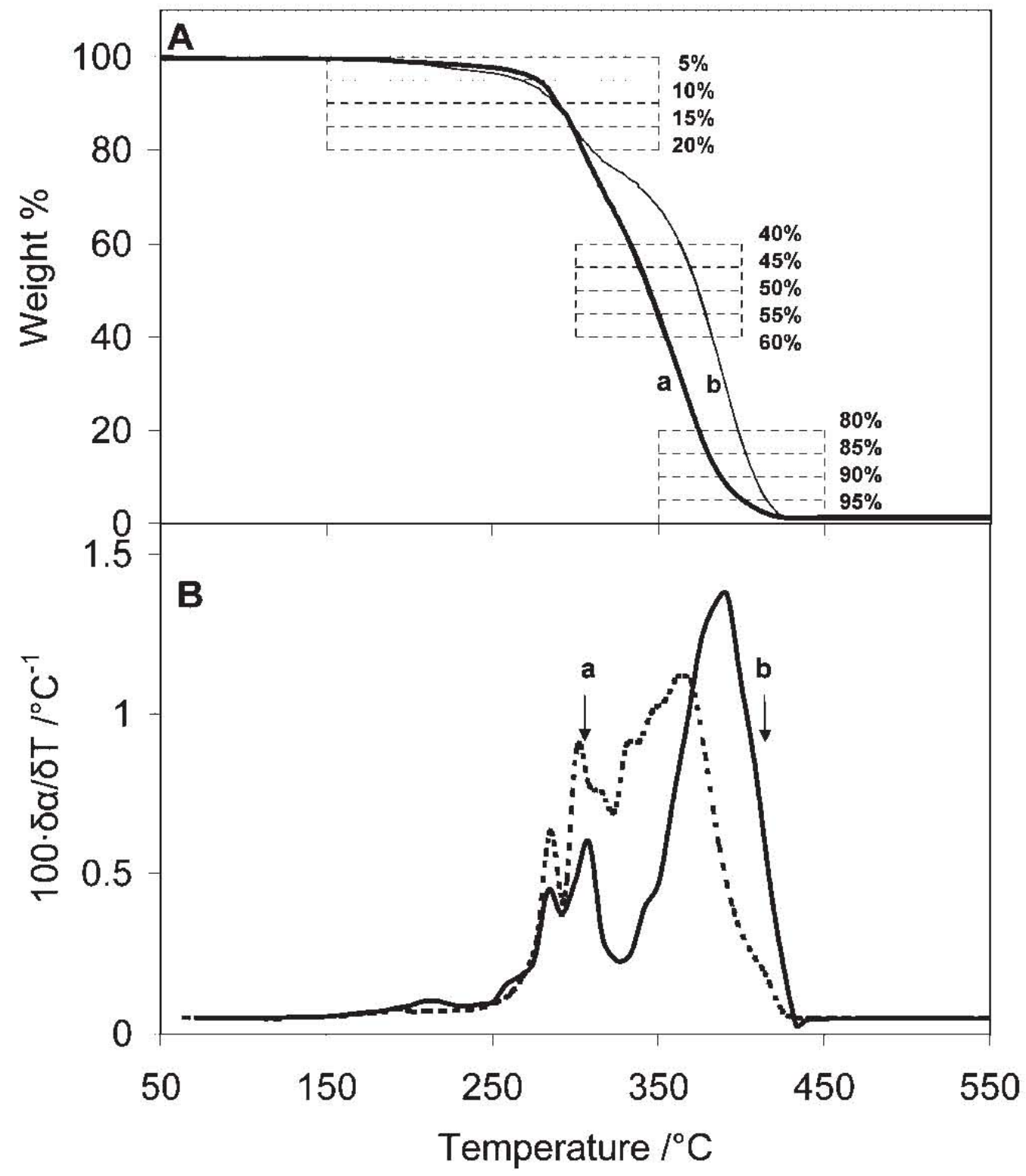

(A) TGA curves for: (a) pure PMMA; (b) PMMA/CHM-4B synthesized via bulk polymerization.

(B) DTG curves for: (a) pure PMMA; (b) PMMA/CHM-4B synthesized via bulk polymerization. 


\section{Figure 5}

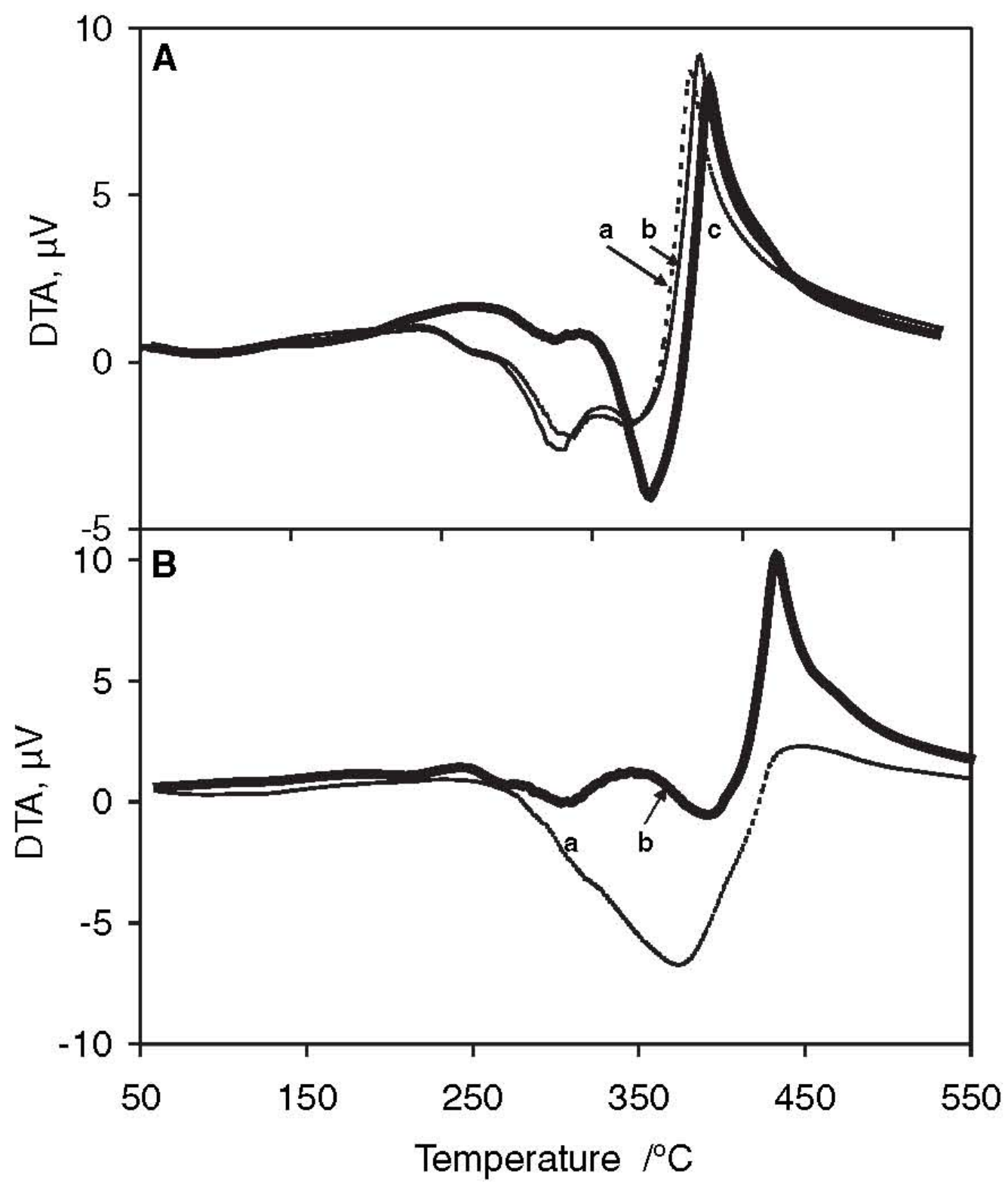

(A) TGA curves for: (a) commercial PMMA; (b) PMMA/CHM-0; (c) PMMA/CHM-3 composite.

(B) DTG curves for: (a) pure PMMA; (b) PMMA/CHM-4B synthesized via bulk polymerization. 
Figure 6

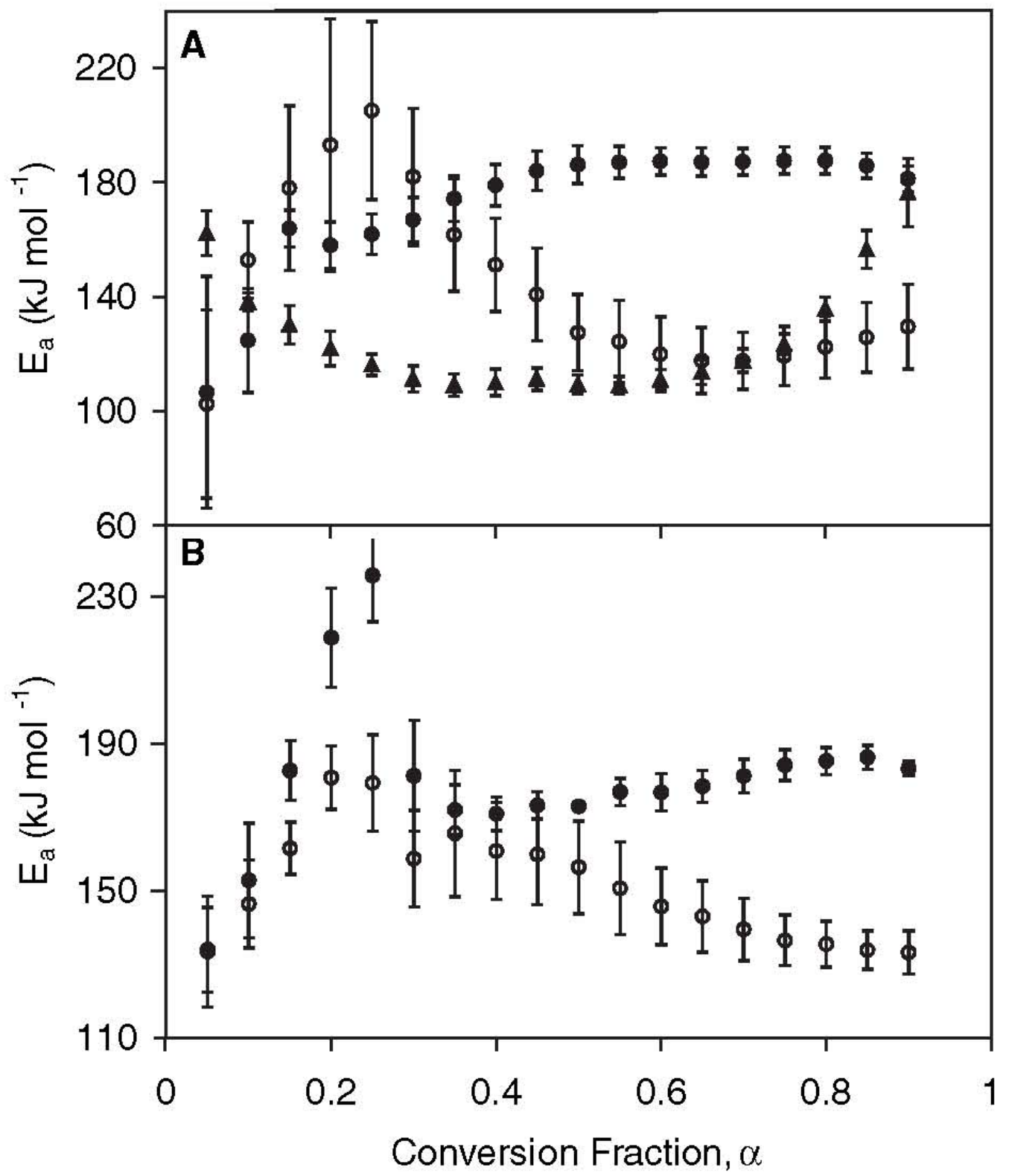

(A) Plot of $E_{a}$ values versus extent to decomposition, $\alpha$, for the non-isothermal degradation of commercial PMMA ( $\mathbf{\Delta})$, PMMA/CHM-0 (०), and PMMA/CHM-3 (•).

(B) Plot of $E_{a}$ values $\alpha$ versus for the non-isothermal degradation of pure PMMA ( 0 ) and PMMA/CHM-4B (•) synthesized via bulk polymerization.

Polymers for Advanced Technology, Vol. 17, No. 4 (April 2006): pg. 312-319. DOI. This article is (C Wiley and permission has been granted for this version to appear in e-Publications@Marquette. Wiley does not grant permission for this article to be further copied/distributed or hosted elsewhere without the express permission from Wiley. 
NOT THE PUBLISHED VERSION; this is the author's final, peer-reviewed manuscript. The published version may be accessed by following the link in the citation at the bottom of the page.

Figure 7

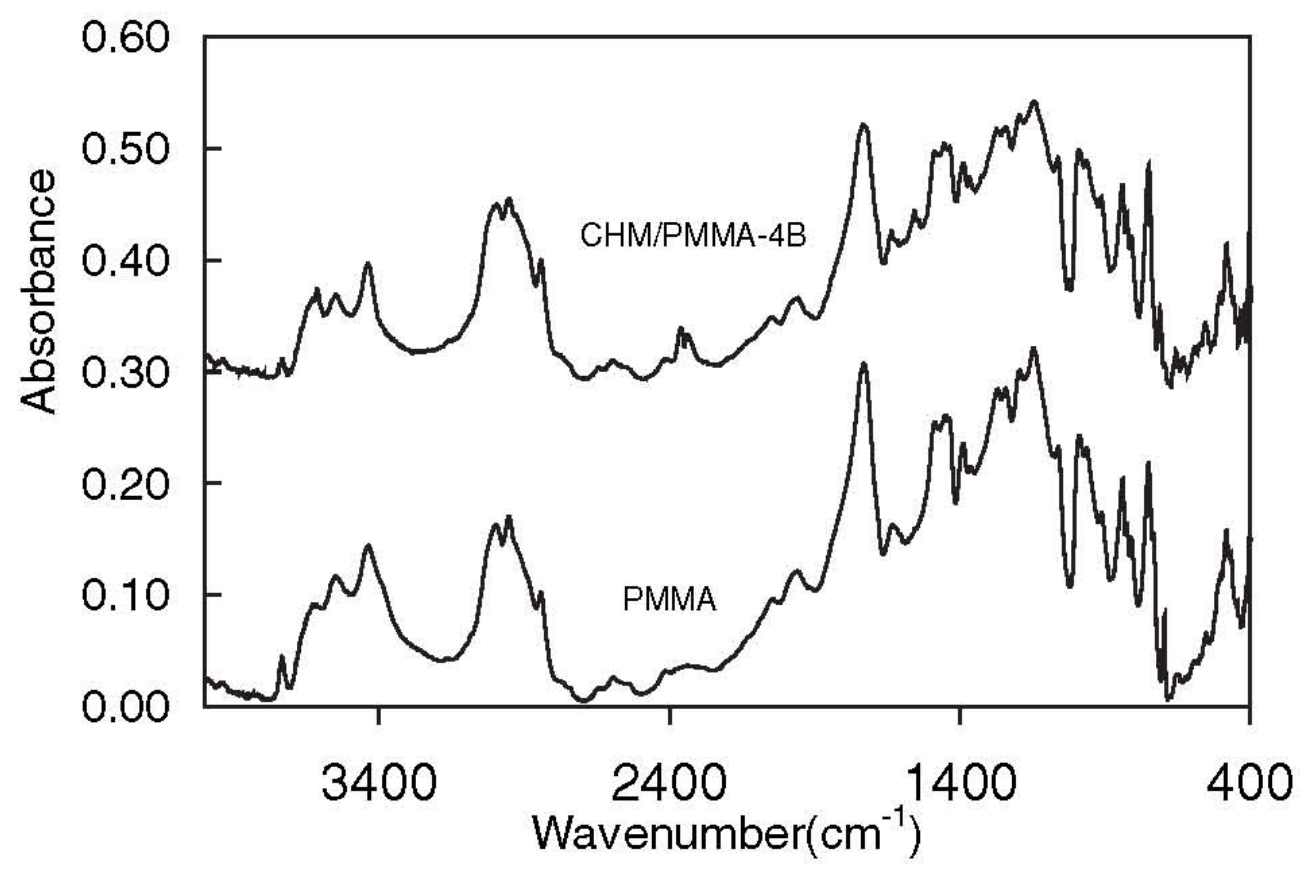

FT-IR spectra of pure PMMA and PMMA/CHM-4B collected at room temperature. The patterns are offset for clarity but otherwise not scaled. 
NOT THE PUBLISHED VERSION; this is the author's final, peer-reviewed manuscript. The published version may be accessed by following the link in the citation at the bottom of the page.

\section{Figure 8}

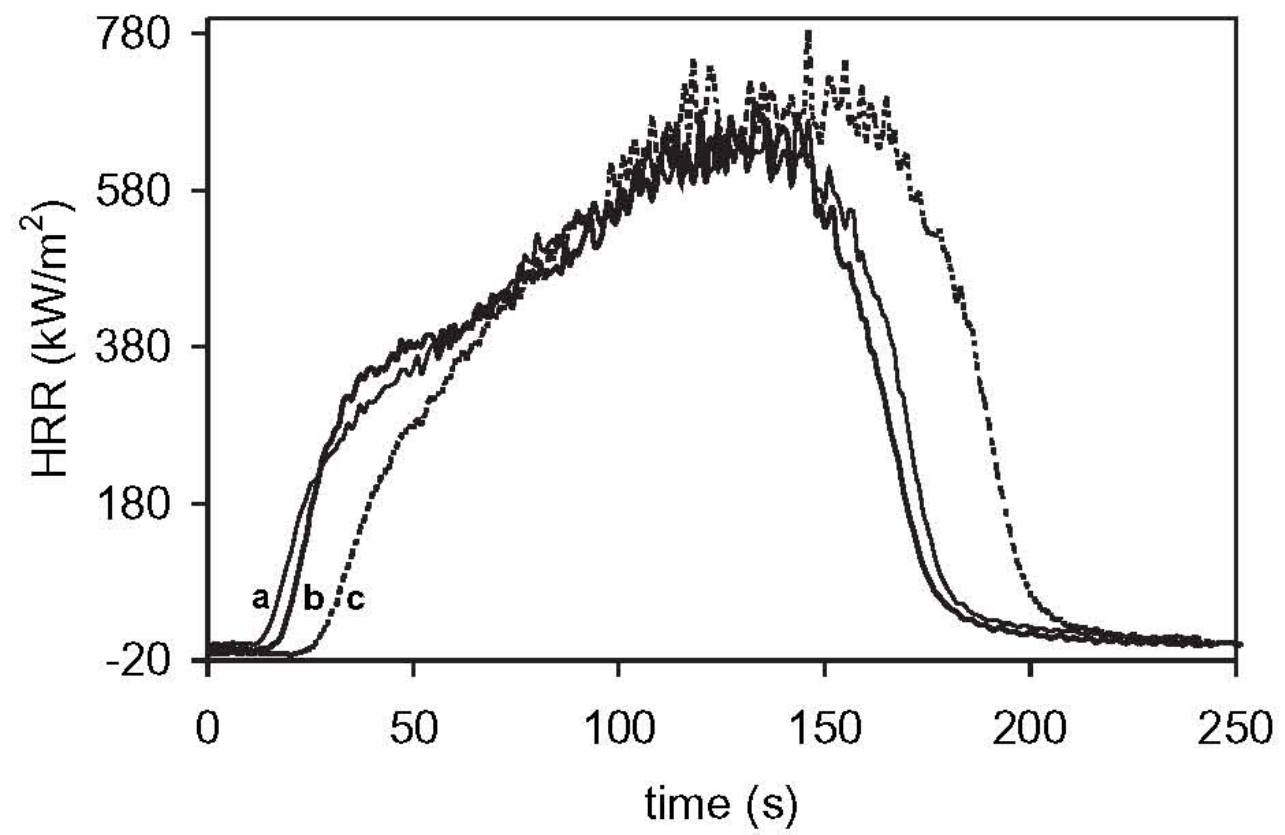

Heat release rate (HRR) curves for (a) PMMA/CHM-0, (b) PMMA/CHM-3, and (c) commercial PMMA from cone calorimetry measurements at a heat flux of $35 \mathrm{~kW} \mathrm{~m}^{-2}$. 